\title{
PENGARUH KONSEP DIRI, KEMANDIRIAN, MOTIVASI DAN LINGKUNGAN BELAJAR TERHADAP PRESTASI BELAJAR EKONOMI SISWA KELAS XI IPS SMA NEGERI DI KABUPATEN GRESIK
}

\author{
Tri Ervina Kristi Wiyani *
}

\begin{abstract}
This study aimed to determine the effects of self-concept, self-reliance, motivation and learning environment for economic achievement in grade XI of Social class of all State Senior high schools in Gresik for academic year 2012/2013. Population was 821 students. Sample was 269 students selected by using sampling technique simple random sampling. Data were collected by questionnaires and documentation methods. The method of analysis in this study was a quantitative analysis, the multiple linear regressions. Results showed there is no partial effect on self-concept to achievement of economic, there is a partial effect on the learning achievement of economic independence, there is a partial effect on the learning achievement of economic motivation, there is no partial effect of learning environment for economic achievement, and there are no simultaneous effect on self-concept, self-reliance, motivation and learning environment on the learning achievement of economic
\end{abstract}

Keywords: self-concept, self-reliance, motivation and learning environment

\section{PENDAHULUAN}

$\mathrm{P}$ endidikan merupakan aspek penting yang menentukan kemajuan suatu bangsa. Pendidikan mempunyai peranan yang sangat besar dalam membentuk karakter, perkembangan ilmu, dan mental generasi muda yang nantinya akan tumbuh menjadi generasi yang mampu bersaing. Melalui pendidikan suatu negara dapat menciptakan sumber daya manusia yang berkulitas yang mampu bersaing dalam menghadapi tantangan globalisasi. Hal ini menunjukkan bahwa pendidikan merupakan sentral dalam pembangunan yang sasarannya adalah sumber daya manusia.

Penyelenggaraan pendidikan dapat dilaksanakan melalui dua jalur yaitu jalur pendidikan formal dan jalur pendidikan non formal. Pencapaian keberhasilan tujuan pendidikan tersebut bergantung pada proses belajar yang dialami siswa baik ketika berada di sekolah maupun diluar sekolah. Dalam pendidikan formal, belajar menunjukkan adanya perubahan yang sifatnya positif sehingga pada tahap akhir akan didapat keterampilan, kecakapan, dan pengetahuan baru. Prestasi belajar merupakan bagian akhir dari proses belajar yang dapat menunjukkan tingkat keberhasilan belajar siswa. Tu'us (2004:75) menyatakan bahwa prestasi belajar adalah penguasaan pengetahuan atau keterampilan yang dikembangkan oleh mata pelajaran, lazimnya ditunjukkan dengan nilai tes atau angka nilai yang diberikan oleh guru.

Prestasi belajar siswa dapat dilihat dari nilai yang peroleh siswa pada setiap mata pelajaran. Siswa dikatakan berhasil jika dapat mencapai batas Kriteria Ketuntasan Minimal *) Guru Ekonomi SMA Negeri 1 Gresik 
(KKM) yang telah ditentukan oleh sekolah yang bersangkutan. Fenomena yang terjadi di Kabupaten Gresik saat ini menunjukkan bahwa prestasi belajar siswa masih rendah hal ini dapat dilihat bahwa di setiap sekolah masih terdapat siswa yang belum dapat mencapai Kriteria Ketuntasan Minimal. Apabila melihat pencapaian prestasi belajar siswa yang masih berada dibawah kriteria ketuntasan minimal, dapat diketahui bahwa tingkat pencapaian prestasi belajar siswa dapat dikatakan belum maksimal. Sedangkan untuk jurusan IPS, mata pelajaran ekonomi merupakan salah satu mata pelajaran yang menentukan kelulusan dalam ujian nasional.

Pencapaian prestasi belajar oleh siswa tersebut tidak terlepas dari faktor-faktor yang mempengaruhi belajar itu sendiri. Berdasarkan faktor-faktor yang mempengaruhi tersebut perlu diketahui dan diteliti. Faktor yang berasal dari dalam diri siswa merupakan salah satu faktor penting dalam menentukan keberhasilan pembelajaran. Hal ini dikarenakan dalam proses belajar mengajar sasaran utamanya adalah siswa itu sendiri sebagai subyek belajar. Namun selain didukung oleh faktor internal siswa juga perlu pendukung dari faktor eksternal siswa.

Konsep diri merupakan salah satu faktor intrinsik yang dapat mempengaruhi penyesuaian diri seseorang dan hal ini merupakan faktor penting dalam perkembangan diri seseorang. Konsep diri akan berpengaruh besar terhadap perilaku yang akan ditampilkan oleh seseorang, sehingga siswa yang memiliki konsep diri yang positif akan telihat optimis, penuh percaya diri, dan selalu bersikap positif terhadap segala sesuatu. Siswa yang mempunyai konsep diri yang positif akan selalu menghargai dirinya dan melihat hal-hal positif yang dapat dilakukan demi keberhasilan dimasa yang akan datang dalam hal ini adalah prestasi belajar. Fenomena yang terjadi menunjukkan bahwa pada kenyataannya tidak semua siswa selalu memiliki konsep diri yang positif melainkan masih terdapat berbagai faktor yang membuat siswa mempunyai kencenderungan konsep diri negatif. Hal ini dapat dilihat dari ketidakpercayaan diri dari siswa yang mengakibatkan siswa mempunyai kecenderungan pesimistis. Hal tersebut tentunya akan berpengaruh terhadap aktivitas siswa dalam pembelajaran dan prestasi belajar.

Syah (2005) menyatakan bahwa konsep diri yang positif akan menimbulkan rasa percaya diri siswa yang akhirnya sikap ini akan memunculkan sikap kemandirian pada dirinya pula. Tirtarahardja dan S.L La Sulo (2005:50) menyatakan bahwa kemandirian belajar adalah aktivitas belajar yang berlangsungnya lebih didorong oleh kemauan sendiri, pilihan sendiri, dan tanggung jawab sendiri. Fenomena yang terjadi saat ini menunjukkan bahwa kemandirian siswa dapat dikatakan masih rendah. Hal ini dapat dibuktikan bahwa masih banyak siswa yang malas belajar dan hanya akan belajar ketika akan ada ujian, serta lebih percaya dan bergantung pada temannya pada saat mengerjakan tugas maupun evaluasi.

Selain konsep diri dan kemandirian, aspek motivasi dari siswa merupakan salah satu faktor internal siwa yang dapat menunjang keberhasilan. Motivasi merupakan bagian dari aspek psikologi dalam diri individu yang mampu membangkitkan, memunculkan, mengarahkan, dan menjaga sesuatu perilaku. Keberadaan motivasi dalam proses belajar merupakan faktor penting yang harus dimiliki siswa karena dengan motivasi akan menciptakan kekuatan-kekuatan dari dalam diri individu untuk mendorong berbuat sesuatu. Namun pada kenyataanya fenomena yang terjadi pada siswa saat ini berdasarkan pengamatan para guru di setiap sekolah menyatakan bahwa motivasi belajar siswa dalam mempelajari ekonomi masih rendah. Hal ini terbukti dari kurangnya minat baca siswa, kurangnya ke- 
aktifan siswa dalam kegiatan belajar mengajar di dalam kelas, dan keterlambatan siswa dalam mengumpulkan tugas-tugas yang diberikan oleh guru.

Pencapaian prestasi belajar selain didukung oleh faktor internal siswa juga perlu pendukung dari faktor eksternal siswa. Lingkungan belajar merupakan faktor yang berasal dari luar diri siswa. Lingkungan belajar meliputi lingkungan keluarga, lingkungan sekolah dan lingkungan masyarakat. Lingkungan belajar yang mendukung proses belajar individu maka akan memberikan dampak positif bagi pembelajaran individu tersebut. Jika dampak positif yang diperoleh oleh individu dari lingkungan belajarnya maka akan menjadikan pendorong prestasi siswa.

Kabupaten Gresik merupakan daerah yang terdiri dari beberapa daerah yang mempunyai karakteristik daerah yang berbeda-beda yaitu daerah industri, daerah pertanian, daerah pesisir pantai dan daerah tambak. Hal ini mengakibatkan lingkungan belajar siswa menjadi semakain beragam pula. Dengan latar belakang lingkungan belajar yang bervariasi tentunya pendidikan di setiap lingkungan belajar siswa yang juga bervariasi dan nantinya akan mempengaruhi prestasi belajar siswa.

Berdasarkan beberapa penelitian terdahulu, terdapat beberapa faktor yang dapat mempengaruhi prestasi belajar diantaranya konsep diri, kemandirian, motivasi dan lingkungan belajar. Keempat faktor ini menjadi penting untuk diteliti kembali karena dalam penelitian terdahulu terbukti keempat faktor ini signifikan berpengaruh terhadap prestasi belajar siswa. Dengan karakteristik wilayah Kabupaten Gresik yang beragam, menarik untuk dilakukan penelitian untuk menjawab permasalahan tentang adakah pengaruh konsep diri, kemandirian, motivasi dan lingkungan belajar terhadap prestasi belajar ekonomi siswa kelas XI IPS SMA Negeri di Kabupaten Gresik

William D Brooks dalam Rakhmat (2003:99) Konsep diri adalah pandangan dan perasaan seseorang tentang dirinya baik yang bersifat psikologis, sosial maupun fisik. Konsep diri merupakan penentu sikap individu dalam bertingkah laku, artinya perilaku individu akan selaras dengan cara individu memandang dirinya sendiri. Menurut Desmita (2010:182) konsep diri dapat mempengaruhi perilaku siswa dan mempunyai hubungan yang sangat menentukan proses pendidikan dan prestasi siswa. Dalam kegiatan pembelajaran konsep diri ini merupakan kunci untuk membangun komunikasi baik dan terbuka antara guru dan murid sehingga menciptakan partisipasi aktif antara keduanya dalam kegiatan belajar mengajar. Menurut Calhoun dan Acocella dalam Desmita (2010:166) menyebutkan terdapat tiga dimensi utama dari konsep diri, yaitu: dimensi pengetahuan, dimensi pengharapan dan dimensi penilaian.

Syah (2005) menyatakan bahwa konsep diri yang positif akan menimbulkan rasa percaya diri siswa yang akhirnya sikap ini akan memunculkan sikap kemandirian pada dirinya pula. Tirtarahardja dan S.L La Sulo (2005:50) menyatakan bahwa kemandirian belajar adalah aktivitas belajar yang berlangsungnya lebih didorong oleh kemauan sendiri, pilihan sendiri, dan tanggung jawab sendiri. Dorongan dari internal individu memiliki kunci pokok dalam kegiatan belajar anak. Perolehan hasil belajar yang didapat anak, baik keterampilan maupun kompetensi tertentu akan mampu dicapai jika dialami sendiri dalam proses perolehan hasil belajar tersebut. Dengan kemandirian belajar siswa akan belajar menguasai materi pelajaran dengan usaha sendiri tanpa adanya guru atau disuruh orang tua sehingga siswa akan cenderung positif dan aktif dalam belajar untuk mencapai tujuan dengan menguasai materi dan memperoleh prestasi yang memuaskan.

Kegiatan belajar dalam proses pendidikan disekolah merupakan kegiatan yang paling 
fundamental. Dalam pembelajaran siswa merupakan subyek utamanya. Berhasil tidaknya pencapaian tujuan pendidikan bergantung pada berbagai macam faktor salah satunya yaitu dari siswa itu sendiri. Faktor dari diri siswa tersebut yaitu dapat berupa motivasi. Motivasi dapat mendorong timbulnya perbuatan yang dilakukan oleh seorang siswa yaitu belajar. Menurut Djamarah (2011:148) mengemukakan bahwa dalam proses belajar, motivasi sangat diperlukan sebab seseorang yang tidak mempunyai motivasi dalam belajar tidak akan mungkin melakukan aktivitas belajar. Sedangkan Ginting (2010:86) menyatakan bahwa yang dimaksud motivasi dalam pembelajaran adalah sesuatu yang menggerakkan atau mendorong siswa untuk belajar atau menguasai materi pelajaran yang sedang diikutinya. Berdasar pengertian tersebut dapat disimpulkan bahwa motivasi belajar adalah keinginan atau dorongan yang kuat dalam diri siswa untuk belajar.

Menurut Uno (2008:23) indikator motivasi dalam belajar tersebut dapat diklasifikasikan sebagai berikut: adanya hasrat keinginan berhasil, adanya dorongan dan kebutuhan dalam balajar, adanya harapan dan cita-sita masa depan, adanya penghargaan dalam belajar, adanya kegiatan yang menarik dalam belajar, adanya lingkungan yang kondusif sehingga memungkinkan seorang siswa dapat belajar dengan baik.

Dalam proses belajar mengajar lingkungan merupakan sumber belajar yang berpengaruh terhadap proses pembelajaran yang berlangsung didalamnya. Lingkungan belajar merupakan salah satu faktor dari banyak faktor yang dapat mempengaruhi belajar yang pada akhirnya akan berpengaruh terhadap prestasi belajar siswa. Menurut Suwarno (2006:39) lingkungan belajar adalah lingkungan yang melingkupi terjadinya proses pendidikan. Sedangkan menurut Saroni (2006:82) lingkungan belajar sebagai segala sesuatu yang berhubungan dengan tempat proses pembelajaran dilakukan.

Kegiatan belajar dalam proses pendidikan disekolah merupakan kegiatan yang paling fundamental. Namun, dalam belajar siswa tidak hanya belajar di salah satu lingkungan saja, melainkan siswa belajar di semua lingkungan dimana siswa tersebut tinggal. Lingkungan-lingkungan tersebut merupakan lingkungan belajar bagi siswa. Lingkungan tersebut akan saling mendukung satu sama lain.

Slameto (2010:60) menyebutkan bahwa belajar dipengaruhi oleh faktor intern dan ekstern. Hal ini membuktikan bahwa selain faktor intern faktor ekstern yaitu lingkungan belajar yang meliputi lingkungan keluarga, dan lingkungan sekolah juga mempunyai pengaruh besar terhadap hasil belajar atau pencapaian prestasi belajar siswa. Lingkungan keluarga dan lingkungan sekolah yang mendukung belajar siswa akan dapat pula mendukung keberhasilan belajar siswa.

Berdasarkan kajian pustaka diatas, peneliti merumuskan hipotesis sebagai berikut :

1. Diduga ada pengaruh signifikan konsep diri terhadap prestasi belajar ekonomi siswa kelas XI IPS SMA Negeri di Kabupaten Gresik.

2. Diduga ada pengaruh signifikan kemandirian terhadap prestasi belajar ekonomi siswa kelas XI IPS SMA Negeri di Kabupaten Gresik.

3. Diduga ada pengaruh signifikan motivasi terhadap prestasi belajar ekonomi siswa kelas XI IPS SMA Negeri di Kabupaten Gresik.

4. Diduga ada pengaruh signifikan lingkungan belajar terhadap prestasi belajar ekonomi siswa kelas XI IPS SMA Negeri di Kabupaten Gresik.

5. Diduga ada pengaruh signifikan konsep diri, kemandirian, motivasi dan lingkungan belajar terhadap prestasi belajar ekonomi siswa kelas XI IPS SMA Negeri di Kabupaten Gresik. 


\section{METODE PENELITIAN}

Pendekatan dalam penelitian ini adalah pendekatan kuantitatif. Penelitian ini dirancang dengan menggunakan penelitian eksplanatory. Variabel yang digunakan pada penelitian ini adalah prestasi belajar (Y), serta konsep diri (X1), kemandirian (X2), motivasi (X3), dan lingkungan belajar (X4).

Populasi dalam penelitian ini adalah siswa kelas XI IPS SMA Negeri di Kabupaten Gresik tahun pelajaran 2012/2013 yaitu sebanyak 821 siswa. Sampel penelitian sebanyak 269 siswa ditetapkan dengan teknik proporsional. Data dikumpulkan dengan penyebaran kuisioner dan dokumentasi. Kuisioner disusun berdasarkan variabel penelitian dan indikator penelitian dengan skala pengukuran instrumen menggunakan skala likert. Teknik analisis menggunakan analisis uji statistik $F$ dan uji t. Uji F digunakan untuk menguji signifikansi pengaruh variabel konsep diri, kemandirian, motivasi dan lingkungan belajar terhadap prestasi belajar ekonomi. Uji t digunakan untuk menguji signifikansi pengaruh konsep diri terhadap prestasi belajar ekonomi, pengaruh kemandirian terhadap prestasi belajar ekonomi, pengaruh motivasi terhadap prestasi belajar ekonomi, dan pengaruh lingkungan belajar terhadap prestasi belajar ekonomi.

\section{HASIL PENELITIAN DAN PEMBAHASAN}

\section{Hasil Penelitian}

Model regresi yang diperoleh berdasarkan hasil penelitian, dapat dituliskan dalam bentuk persamaan regresi adalah sebagai berikut : $\mathrm{PB}=32,634+0,323 \mathrm{KD}+0,183 \mathrm{KM}$ $+0,332 \mathrm{MV}+0,062 \mathrm{LB}+\mathrm{e}_{\mathrm{i}}$. Dari persamaan tersebut, ketempat variabel bebas memiliki koefisien regresi dengan arah positif. Hal ini berarti bahwa semakin tinggi konsep diri, kemandirian, motivasi dan lingkungan belajar akan meningkatkan prestasi belajar ekonomi siswa. Hasil uji F berdasarkan uji ANOVA atau uji statistik F, model menunjukkan nilai $\mathrm{F}$ sebesar 79,680 dengan probabilitas sebesar 0,000 kurang dari $5 \%$ hal ini berarti bahwa prestasi belajar dapat dijelaskan oleh variabel konsep diri, kemandirian, motivasi, dan lingkungan belajar secara bersama-sama atau dengan kata lain semua variabel bebas secara bersama-sama merupakan penjelas yang signifikan terhadap variabel terikat.

Koefisien determinasi (R-square) yang dihasilkan dalam penelitian ini sebesar 0,547 menunjukkan konsep diri (X1), kemandirian (X2), motivasi (X3) dan lingkungan belajar (X4) berpengaruh terhadap prestasi belajar (Y) sebesar 54,7\% sedangkan sisanya 45,3\% dipengaruhi oleh faktor lain yang tidak dibahas pada penelitian ini.

Lebih lanjut uji parsial menunjukkan semua variabel mempunyai pengaruh yang signifikan. Uji parsial menunjukkan nilai t-hitung pada variabel konsep diri (X1) sebesar 5,000 dengan tingkat signifikan sebesar 0,000, t-hitung pada variabel kemandirian (X2) sebesar 3,849 dengan tingkat signifikan sebesar 0,000, t-hitung pada variabel motivasi (X3) sebesar 6,204 dengan tingkat signifikan sebesar 0,000, t-hitung pada variabel lingkungan belajar (X4) sebesar 2,182 dengan tingkat signifikan sebesar 0,030. Dengan tingkat signifikasi yang kurang dari 5\% berarti menunjukkan bahwa konsep diri, kemandirian, motivasi dan lingkungan belajar secara parsial berpengaruh signifikan terhadap prestasi belajar (Y). 


\section{Pembahasan}

1. Pengaruh Konsep Diri Terhadap Prestasi Belajar

Berdasarkan hasil penelitian mengenai pengaruh konsep diri terhadap prestasi belajar menunjukkan bahwa konsep diri berpengaruh signifikan positif terhadap prestasi belajar. Hipotesis kerja yang menyatakan "Diduga ada pengaruh konsep diri terhadap prestasi belajar ekonomi siswa kelas XI IPS SMA Negeri di Kabupaten Gresik" teruji kebenarannya. Hal ini ditunjukkan melalui hasil persamaan regresi linier berganda diperoleh nilai t-hitung pada variabel konsep diri (X1) sebesar 5,000 dengan tingkat signifikan sebesar 0,000 kurang dari 5\%, artinya semakin tinggi konsep diri siswa semakin tinggi prestasi belajar siswa.

Lebih lanjut berdasarkan koefisien regresi pada variabel konsep diri sebesar 0,323, nilai positif pada variabel ini menunjukkan bahwa konsep diri memiliki pola hubungan yang searah dengan prestasi belajar yaitu semakin tinggi konsep diri maka semakin tinggi prestasi belajar siswa.

Hasil temuan tersebut sesuai kajian teori dalam Desmita (2010:182) yang menyatakan bahwa konsep diri mempengaruhi perilaku peserta didik dan mempunyai hubungan yang sangat menentukan proses pendidikan dan prestasi belajar mereka. Desmita (2010:171) juga menyatakan bahwa sejumlah ahli psikologi dan pendidikan berkeyakinan bahwa konsep diri dan prestasi belajar mempunyai hubungan yang erat. Nylor (1972) mengemukakan bahwa banyak penelitian yang membuktikan hubungan yang positif yang kuat antara konsep diri dengan prestasi belajar siswa di sekolah.

Selain berdasarkan teori penelitian ini juga didukung oleh kajian empiris yaitu penelitian Frederic Guay, Michel Boivin and Herbert W. Marsh (2003) yang penelitiannya menunjukkan bahwa terdapat hubungan antara konsep diri dengan prestasi akademik. Begitu juga penelitian Rensi dan Luci Rini Sugiarti (2010) yang menyatakan bahwa dukungan sosial dan konsep diri terhadap prestasi belajar siswa.

\section{Pengaruh Kemandirian Terhadap Prestasi Belajar}

Berdasarkan hasil penelitian mengenai pengaruh kemandirian terhadap prestasi belajar menunjukkan bahwa kemandirian berpengaruh signifikan positif terhadap prestasi belajar. Hipotesis kerja yang menyatakan "Diduga ada pengaruh kemandirian terhadap prestasi belajar ekonomi siswa kelas XI IPS SMA Negeri di Kabupaten Gresik" teruji kebenarannya. Hal ini ditunjukkan melalui hasil persamaan regresi linier berganda diperoleh nilai t-hitung pada variabel kemandirian (X2) sebesar 3,849 dengan tingkat signifikan sebesar 0,000 kurang dari 5\%, artinya semakin tinggi kemandirian siswa semakin tinggi prestasi belajar siswa.

Koefisien regresi pada variabel kemandirian sebesar 0,183 menunjukkan bahwa kemandirian memiliki pola hubungan yang searah dengan prestasi belajar yaitu semakin tinggi kemandirian maka semakin tinggi prestasi belajar siswa.

Hasil penelitian ini sesuai dengan teori yang dinyatakan oleh Umar Tirtahardja dan La Sulo (2005:50) bahwa "kemandirian dalam belajar adalah aktivitas belajar yang berlangsungnya lebih didorong oleh kemauan sendiri, pilihan sendiri, dan tanggung jawab sendiri". Dorongan dari internal individu memiliki kunci pokok dalam kegiatan belajar anak. Perolehan hasil belajar yang didapat anak, baik keterampilan maupun kompetensi tertentu akan mampu dicapai jika dialami sendiri dalam proses perolehan hasil belajar tersebut. 
Hasil penelitian ini juga didukung oleh kajian empirik dari penelitian terdahulu yaitu penelitian Nasrobah (2009) yang menunjukkan bahwa terdapat hubungan yang signifikan antara kemandirian belajar, komunikasi interpersonal dan identitas sosial terhadap hasil belajar. Serta Abdul Kadir, Andi Tanra Tellu dan Amirudin Kasim, (2011) dengan hasil penelitian yang menunjukkan bahwa perhatian orangtua, konsep diri dan kemandirian belajar siswa mempunyai pengaruh yang signifikan terhadap prestasi belajar siswa.

\section{Pengaruh Motivasi Terhadap Prestasi Belajar}

Berdasarkan hasil penelitian mengenai pengaruh motivasi terhadap prestasi belajar menunjukkan bahwa motivasi berpengaruh signifikan positif terhadap prestasi belajar. Hipotesis kerja yang menyatakan "Diduga ada pengaruh motivasi terhadap prestasi belajar ekonomi siswa kelas XI IPS SMA Negeri di Kabupaten Gresik" teruji kebenarannya. Hal ini ditunjukkan melalui hasil persamaan regresi linier berganda diperoleh nilai t-hitung pada variabel motivasi (X3) sebesar 6,204 dengan tingkat signifikan sebesar 0,000 kurang dari 5\%, artinya semakin tinggi motivasi siswa semakin tinggi prestasi belajar siswa.

Berdasarkan koefisien regresi pada variabel motivasi sebesar 0,332 menunjukkan bahwa motivasi memiliki pola hubungan yang searah dengan prestasi belajar yaitu semakin tinggi motivasi maka semakin tinggi prestasi belajar siswa.

Hasil penelitian ini didukung oleh teori Djamarah (2011:148) yang menyatakan bahwa dalam proses belajar motivasi sangat diperlukan sebab seseorang yang tidak mempunyai motivasi dalam belajar tidak akan mungkin melakukan aktivitas belajar. Selain itu didukung pula oleh teori yang dinyatakan oleh Dimyati (2006:85) bahwa motivasi belajar mempunyai peranan penting bagi siswa yaitu:

1. Menyadarkan kedudukan pada awal belajar, proses dan hasil akhir

2. Menginformasikan tentang kekuatan usaha belajar, yang dibandingkan dengan teman sebaya.

3. Mengarahkan kegiatan belajar.

4. Membesarkan semangat belajar.

5. Menyadarkan tentang adanya perjalanan belajar dan kemudian bekerja (disela-sela istirahat atau bermain) yang berkesinambungan, individu dilatih untuk menggunakakn kekuatannya sedemikian rupa sehingga dapat berhasil.

Selain berdasarkan kajian teori hasil penelitian ini juga didukung oleh kajian empirik yaitu dari hasil penelitian yang dilakukan oleh Faatchiah Kertamuda (2008) yang menyimpulkan bahwa motivasi belajar berpengaruh signifikan terhadap prestasi belajar. Selain itu penelitian Gul Shahzad Sarwar, Carlos Zerpa, Kristal Hachey, Merielle Simon dan Chistina van Barneveld (2012) yang menunjukkan motivasi berpengaruh secara signifikan terhadap prestasi akademik siswa.

\section{Pengaruh Lingkungan Belajar Terhadap Prestasi Belajar}

Berdasarkan hasil penelitian mengenai pengaruh lingkungan belajar terhadap prestasi belajar menunjukkan bahwa lingkungan belajar berpengaruh signifikan terhadap prestasi belajar. Hipotesis kerja yang menyatakan "Diduga ada pengaruh lingkungan belajar terhadap prestasi belajar ekonomi siswa kelas XI IPS SMA Negeri di Kabupaten Gresik" teruji kebenarannya. Hal ini ditunjukkan melalui hasil persamaan regresi linier berganda diperoleh nilai t-hitung pada variabel lingkungan belajar (X4) sebesar 2,182 dengan tingkat signifikan sebesar 0,030 kurang dari 5\%. Artinya semakin baik lingkungan 
belajar siswa semakin tinggi prestasi belajar siswa. Koefisien regresi pada variabel konsep diri yang bernilai positif menunjukkan bahwa lingkungan belajar memiliki pola hubungan yang searah dengan prestasi belajar yaitu semakin baik lingkungan belajar maka semakin tinggi prestasi belajar siswa.

Hasil penelitian ini sesuai dengan teori Tirtaraharja (2005:166) mengemukakan sepanjang hidupnya manusia selalu dipengaruhi oleh tiga lingkungan pendidikan yaitu lingkungan keluarga, lingkungan sekolah dan lingkungan masyarakat. Dalam penelitian ini lingkungan dibatasi pada lingkungan keluarga dan lingkungan sekolah. Sesuai dengan batasan tersebut teori menurut Slameto (2010:64) siswa yang belajar akan menerima pengaruh dari lingkungan keluarga, lingkungan sekolah dan lingkungan masyarakat dan juga Dalyono (2005:59) keadaan sekolah mempengaruhi tingkat keberhasilan belajar.

Selain berdasarkan kajian teori hasil penelitian ini juga didukung oleh kajian empirik yaitu dari penelitian yang dilakukan oleh Wiyono (2003) dengan hasil penelitian yang menyatakan bahwa terdapat hubungan positif yang signifikan antara Lingkungan Belajar, Kebiasaan Belajar, dan Motivasi Belajar dengan Prestasi Belajar Siswa baik secara parsial maupun bersama-sama.

5. Pengaruh Konsep Diri, Kemandirian, Motivasi dan Lingkungan Belajar Terhadap Prestasi Belajar

Berdasarkan hasil penelitian secara parsial konsep siri, kemandirian, motivasi dan lingkungan belajar berpengaruh signifikan terhadap prestasi belajar. Begitu juga dengan secara simultan atau bersama-sama, konsep diri, kemandirian, motivasi dan lingkungan belajar berpengaruh signifikan terhadap prestasi belajar. Hal ini dapat dilihat dari hasil uji F diperoleh Fhitung sebesar 79,680 dengan tingkat signifikan sebesar 0,000 kurang dari $5 \% \quad($ sig $<5 \%)$ maka $\mathrm{H} 0$ ditolak dan $\mathrm{H} 1$ diterima, berarti konsep diri (X1), kemandirian (X2) motivasi (X3) dan lingkungan belajar (X4) secara simultan berpengaruh signifikan terhadap prestasi belajar (Y).

Hasil penelitian ini didukung penelitian Dwija (2008) yang menunjukkan bahwa konsep diri, motivasi berprestasi dan perhatian orangtua berpengaruh signifikan terhadap prestasi belajar siswa. Begitu juga penelitian yang dilakukan oleh Abdul Kadir, Andi Tanra Tellu dan Amirudin Kasim, (2011) menunjukkan bahwa perhatian orangtua, konsep diri dan kemandirian belajar siswa mempunyai pengaruh yang signifikan terhadap prestasi belajar siswa.

\section{KESIMPULAN}

Berdasarkan hasil analisis regresi linier berganda, maka simpulan yang dapat diambil adalah sebagai berikut :

1. Konsep diri berpengaruh signifikan terhadap prestasi belajar ekonomi siswa kelas XI IPS SMA Negeri di Kabupaten Gresik. Hal ini berarti semakin baik konsep diri siswa maka akan semakin baik prestasi belajar siswa.

2. Kemandirian berpengaruh signifikan terhadap prestasi belajar ekonomi siswa kelas XI IPS SMA Negeri di Kabupaten Gresik. Hal ini berarti semakin baik kemandirian siswa maka akan semakin baik prestasi belajar siswa.

3. 3. Motivasi berpengaruh signifikan terhadap prestasi belajar ekonomi siswa kelas XI IPS SMA Negeri di Kabupaten Gresik. Hal ini berarti semakin baik motivasi siswa 
maka akan semakin baik prestasi belajar siswa.

4. Lingkungan belajar berpengaruh signifikan terhadap prestasi belajar ekonomi siswa kelas XI IPS SMA Negeri di Kabupaten Gresik. Hal ini berarti semakin baik lingkungan belajar siswa maka akan semakin baik prestasi belajar siswa.

5. Konsep diri, kemandirian, motivasi dan lingkungan belajar secara simultan berpengaruh signifikan terhadap prestasi belajar ekonomi siswa kelas XI IPS SMA Negeri di Kabupaten Gresik. Hal ini berarti konsep diri, kemandirian, motivasi dan lingkungan belajar secara simultan berpengaruh signifikan terhadap prestasi belajar. Semakin baik konsep diri, kemandirian, motivasi dan lingkungan belajar maka semakin baik prestasi belajar siswa.

\section{DAFTAR RUJUKAN}

Arikunto, Suharsimi. Prosedur Penelitian : suatu pendekatan Praktik. Jakarta: Rineka Cipta.

Budi, Wiyono. Bambang.2003. Hubungan lingkungan belajar, Kebiasaan belajar dan motivasi belajar dengan prestasi belajar. Jurnal Forum Penelitian Vol. 15. No 1 bulan juni.

Dalyono. 2009. Psikologi Pendidikan. Jakarta: Rineka Cipta

Depdiknas. 2006.Kurikulum 2006 Mata Pelajaran Ekonomi Sekolah Menengah Atas. Jakarta: Depdiknas

Desmita, Psikologi Perkembangan Peserta Didik. Bandung: PT Remaja Rosdakarya

Hamalik, Oemar. 2005. Kurikulum dan Pembelajaran. Jakarta: Bumi Aksara

Hamalik, Oemar.2011. Perencanaan Pengajaran berdasarkan Pembekalan Baru. Jakarta: Sinar Grafika

Hidayati, Kana \& Listyani Endang. 2010. Pengembangan Instrumen Kemandirian Belajar Mahasiswa. Jurnal Penelitian dan Evaluasi Pendidikan. Tahun 14 Nomor. 1

Dwija, I Wayan. 2008. Hubungan antara Konsep Diri, Motivasi Berprestasi dan Perhatian Orang tua dengan Hasil Belajar Sosisologi pada Siswa Kelas II SMK Unggulan di Kota Amlapura. Jurnal Pendidikan dan Pengajaran Undiksha No.1

Kadir, Abdul 2011. Pengaruh Perhatian orang tua, Konsep diri, dan Kemandirian belajar terhadap Prestasi Belajar sSswa pada Mata Pelajaran Biologidi SMA Negeri 2 SIGI BIROMARU. Jurnal Biodidaktis, Volume 4, Nomor 2

Kertamuda, Faatchiah. 2008. Pengaruh Motivasi Belajar terhadap Prestasi Belajar. Jurnal Psikologi Vol. 21 No. 1

Nasrobah, Asep. 2009. Hubungan antara Kemandirian Belajar, Komunikasi interpersonal dan Identitas Sosial dengan Hasil Belajar Agama Islam. Jurnal Teknologi Pendidikan Vol 11 No. 1

Rakhmat, J. 2002. Psikologi Komunikasi. Bandung: PT. Remaja Rosdakarya

Rensi dan Luci Rini Sugiarti. 2010. Dukungan Sosial, Konsep Diri, dan Prestasi Belajar 
Siswa SMP Kristen YSKI Semarang. Jurnal Psikologi Vol.3 No.2

Riduwan, 2006.Belajar Mudah Penelitian Guru, Karyawan dan Peneliti Pemula.Bandung : Alfabeta

Sarwar, Gul Shahzad, Carlos Zerpa, Kristal Hachey, Merielle Simon dan Chistina van Barneveld, 2012. Teaching Practice and Student Motivation that Influence Achievement on Large-Scale Assesment". International Journal of Education. Vol 4 No.3

Saroni, Muhammad.2006. Manajemen Sekolah.Jogjakarta : Ar Ruzz Media

Suwarno, Wiji. 2006. Dasar-dasar Ilmu Pendidikan. Jogjakarta: Ar Ruzz Media

Syah, Muhibbin.2005. Psikologi Pendidikan dengan Pendekatan Baru. Bandung: PT Remaja Rosdakarya .2009. Psikologi Belajar. Jakarta: PT. Raja Grafindo Persada

Tirtarahardja, Umar dan S.L La Sulo. 2005. Pengantar Pendidikan. Jakarta: Rineka Cipta Tu’u, Tulus.2004. Peran Disiplin pada Perilaku dan Prestasi Siswa. Jakarta: Grasindo Uno, Hamzah. 2008. Teori Motivasi dan Pengukurannya. Jakarta: Bumi Aksara 